\title{
DEIKSIS WAKTU DAN RUANG DALAM TRANSKRIPTE DER HOERTEXTE BUKU AJAR NETZWERK B1
}

\author{
Roselina Puspa Dewi ${ }^{1}$, Yunanfathur Rahman² \\ ${ }^{1}$ Universitas Negeri Surabaya, roselina.17020504016@mhs.unesa.ac.id \\ ${ }^{2}$ Universitas Negeri Surabaya, y.rahman@unesa.ac.id
}

\begin{abstract}
Abstrak
Artikel ini mendeskripsikan deiksis waktu dan deiksis ruang dalam Transkripte der Hörtexte buku ajar Netzwerk B1. Dalam belajar Bahasa Jerman, khususnya pada bagian menyimak atau Hörverstehen perlu adanya pemahaman tuturan oleh penutur maupun mitra tutur. Peneliti menganalisis leksem waktu dan leksem ruang yang termasuk deiksis maupun nondeiksis. Teori yang digunakan adalah teori Levinson dengan metode penelitian bahasa. Hasil penelitian ini menunjukkan dalam transkrip bagian Hörverstehen buku ajar Netzwerk B1 terdapat 136 leksem waktu yang merupakan deiksis waktu yang terdiri dari 6 macam deiksis waktu dan 1 macam leksem waktu sebagai non-deiktis. Leksem waktu berdasarkan perhitungan kalender termasuk bersifat deiktis jika digabungkan dengan pengubah deiktis. Sedangkan untuk deiksis ruang ditemukan 148 leksem. Dari leksem ruang yang ditemukan hanya terdapat 5 macam deiksis ruang. Leksem ruang berdasarkan arah dapat termasuk bersifat deiktis maupun non-deiktis.
\end{abstract}

Kata Kunci: deiksis waktu, deiksis ruang, non-deiktis

\begin{abstract}
This article describes the time deixis and place deixis in Transkripte der Hörtexte Netzwerk B1. In learning German, especially in the listening section, it is necessary to understand speech by speakers and speech partners. Researchers analyzed the lexeme of time and lexeme of place, including deictic or non-deictic. The theory used is the Levinson's theory with language research methods. The results of this study indicate that in the transcript of the listening section in Netzwerk B1, there are 136 time lexemes which are time deixis and consist of 6 types of time deixis and 1 type of time lexeme as non-deictic. Time lexemes based on calendar reckoning can be deictic when combined with a deictic modifier. Whereas for place deixis, there are 148 lexemes found. From that there are only 5 types of place deixis. Place lexemes based on direction can be deictic or non-deictic.
\end{abstract}

Keywords: time deixis, place deixis, non-deictic

\section{PENDAHULUAN}

Dalam belajar bahasa asing (bahasa Jerman) terdapat berbagai media untuk membantu meningkatkan kemampuan berbahasa, salah satunya menggunakan buku ajar. Buku ajar Netzwerk B1 terdiri atas beberapa bagian keterampilan berbahasa, di antaranya: Lesen, Schreiben, Sprechen, Sprachbausteine, dan Hören. Pada bagian Hörverstehen, selain mendengar, pembelajar bahasa asing juga perlu memahami apa yang dikatakan oleh penutur maupun mitra tutur. Seperti yang dikatakan Nunan (1991: 17), menyimak dibagi menjadi dua proses, 
yaitu mendengar berupa proses penerimaan bunyi oleh indera pendengar dan memahami berupa hasil olahan informasi yang diterima dan dimengerti oleh otak. Dengan memahami apa yang didengar, pembelajar sekaligus akan mengetahui konteks tuturan. Cahyono (1995, hal 127) menyatakan bahwa apabila konteks tuturan tidak jelas maka tidak dapat memaknai kata-kata dengan tepat sehingga setiap mendengarkan perkataan atau percakapan pada bagian Hörverstehen, pendengar harus benar-benar mengerti konteks tuturan tersebut.

Deiksis dapat diketahui dan dipahami dengan cara mengetahui konteks tuturan yang ada pada setiap tuturan untuk mengerti apa yang sebenarnya ingin disampaikan oleh penutur maupun mitra tutur. Berasal dari kata Yunani deiktikos, deiksis artinya 'hal penunjukan secara langsung'. Deiksis adalah hubungan antara bahasa dan konteks yang tercermin dalam struktur bahasa itu sendiri. Deiksis berkaitan dengan cara mengkodekan bahasa dari konteks tuturan atau ucapan, dengan demikian juga menyangkut interpretasi ucapan bergantung analisis konteks ucapan (Levinson, 1983: 54). Levinson mengklasifikasikan deiksis menjadi 5 (lima) jenis, yaitu deiksis orang (Person deixis), deiksis waktu (Time deixis), deiksis ruang (Place deixis), deiksis wacana (Discourse deixis), dan deiksis sosial (Social deixis). Deiksis orang menunjukkan kata ganti orang atau bentuk pronominal. Deiksis waktu berkaitan dengan kapan tuturan itu dilakukan atau waktu pengkodean dan waktu penerimaan, dalam bahasa Inggris seperti now, then, yesterday, dll, dalam bahasa Jerman terdapat jetzt, früher, gestern, dan sebagainya. Deiksis ruang berkaitan dengan lokasi atau tempat yang relatif terhadap penutur, seperti hier, da, dort, dll. Deiksis wacana menyangkut penggunaan ekspresi dalam beberapa ungkapan dari sebuah wacana. Sedangkan deiksis sosial berkaitan dengan aspek kalimat yang mencerminkan realitas sosial tertentu.

(1) Und Ferienhaus finde ich immer besser als Hotel. Da habe ich meine Ruhe und nicht so viele Leute um mich herum.

(2) X: Immer auf den gleichen Campingplatz?

Y: Ja, da sind wir schon seit 15 Jahren immer. Es ist wirklich schön dort. Wir kennen uns jetzt schon gut aus.

(3) Guten Tag!

Dari 3 contoh di atas, dapat diketahui contoh (1) dan (2) mengandung deiksis ( $d a$ dan jetzt), namun contoh pertama berupa deiksis ruang menggunakan $d a$, karena mengacu 
pada Ferienhaus. Sedangkan contoh kedua terdapat deiksis waktu dengan menggunakan leksem waktu jetzt. mengacu pada saat $\mathrm{Y}$ menuturkan tuturan tersebut. Berbeda dengan dua contoh sebelumnya, contoh ketiga tidak bersifat deiktis atau non-deiktis karena Guten Tag! adalah kata sapaan, tidak ada referen yang dituju.

Dari 5 (lima) deiksis yang diklasifikasikan oleh Levinson, peneliti hanya berfokus pada 2 (dua) deiksis, yaitu deiksis waktu dan deiksis ruang. Menurut Purwo (1984, hal 1-2), bahwa jika suatu kata acuannya berpindah-pindah tergantung penutur, waktu tuturan dan tempat terjadinya tuturan, maka bisa bersifat deiktis. Leksem waktu dan leksem ruang menjadi poin yang digunakan dalam penelitian ini untuk menunjukkan deiksis waktu dan deiksis ruang. Selain itu, Transkripte der Hörtexte buku ajar Netzwerk B1 berupa percakapan seharisehari tidak berupa sebuah wacana ataupun realitas sosial tertentu. Dengan demikian, deiksis waktu dan deiksis ruang memberikan pemahaman dalam proses menyimak pada bagian Hörverstehen buku ajar Netzwerk B1. Oleh karena itu, penelitian ini dilaksanakan.

Penelitian mengenai deiksis sudah pernah dilakukan sebelumnya. Penelitian dengan judul "Deiksis dalam das Jugendmagazin (JUMA) Suatu Analisis Pragmatik" (Mumba, 2019). Metode penelitian yang digunakan Mumba (2019, hal 5) dalam penelitiannya adalah metode deskriptif Pelz dengan menggunakan teori Bünting dan Klein. Hasil penelitian menunjukkan jenis deiksis yang ditemukan dalam JUMA ada 4 jenis, yaitu deiksis persona, deiksis temporal, deiksis lokal dan deiksis objek. Namun di dalam penelitian Mumba (2019) tidak dijelaskan hasil perbandingan dari dua teori yang ada (Bünting dan Klein). Dari sini terlihat perbedaan penelitian ini dengan penelitian yang dilakukan. Penelitian yang dilakukan tidak hanya berfokus pada deiksis waktu dan deiksis ruang, melainkan juga leksem non-deiktis dengan menggunakan teori Levinson.

Berdasarkan pemaparan yang sudah dituliskan di atas, peneliti melakukan penelitian dengan judul "Deiksis Waktu dan Ruang dalam Transkripte der Hörtexte Buku Ajar Netzwerk B1”. Seperti yang sudah dijelaskan sebelumnya, rumusan masalah penelitian ini yaitu bagaimana deiksis waktu dan deiksis ruang yang ada pada Transkripte der Hörtexte buku ajar Netzwerk B1 sehingga 
menghasilkan tujuan penelitian, yakni mendeskripsikan deiksis ruang dan waktu yang ada pada Transkripte der Hörtexte buku ajar Netzwerk B1 dengan teori Levinson.

\section{METODE}

Metode merupakan salah satu komponen dari wujud kegiatan ilmiah ilmu bahasa. Metode bertujuan agar kegiatan praktis terlaksana secara rasional dan terarah untuk mendapatkan hasil yang optimal. Penelitian ini menggunakan metode penelitian bahasa. Metode ini adalah cara kerja yang digunakan untuk memahami dan menjelaskan fenomena objek ilmu bahasa atau cara mendekati, mengamati, menganalisis, dan menjelaskan masalah di dalam objek ilmu bahasa itu sendiri (Kridalaksana dalam Kurniawati, dkk, 2013).

Data diperoleh dari sumber tertulis atau transkrip bagian Hörverstehen (Transkripte der Hörtexte) dalam Buku Ajar Netzwerk B1 yang terbagi menjadi dua file yang berjumlah masing-masing 15 halaman dengan isi 12 bab (Kapitel) (Dengler, dkk: 2017a, 2017b). Sehingga sumber yang digunakan merupakan sumber yang valid. Data penelitian berupa leksem yang tergolong deiksis ruang dan deiksis waktu beserta konteksnya.

Teknik dokumentasi adalah teknik yang digunakan untuk memperoleh informasi maupun data dalam bentuk buku, arsip, dokumen, tulisan berupa laporan serta penjelasan yang dapat mendukung penelitian (Sugiyono, 2015: 329). Teknik pengumpulan data yang digunakan dalam penelitian ini adalah teknik dokumentasi. Hal ini karena peneliti memperoleh data berupa transkrip dengan mengunduh melalui website yang tergolong dalam dokumen publik (Creswell, 2010). Menganalisis data yang ada dengan langkah-langkah sebagai berikut:

1. Mengunduh Transkripte der Hörtexte Netzwerk B1.

2. Menganalisis keseluruhan data dan memperhatikan leksem waktu dan leksem ruang yang mengandung deiksis waktu dan deiksis ruang juga nondeiktis dengan teori Levinson.

3. Mencatat leksem-leksem yang mengandung deiksis waktu dan deiksis ruang juga non-deiktis beserta konteksnya pada kartu data,

4. Memaparkan hasil deiksis waktu dan deiksis ruang yang terdapat dalam Transkripte der Hörtexte buku ajar Netzwerk B1. 


\section{HASIL DAN PEMBAHASAN}

Dalam Transkripte der Hörtexte buku ajar Netzwerk B1, ditemukan sebanyak 136 leksem yang menunjukkan deiksis waktu dan dari data yang terkumpul hanya ada 6 macam deiksis waktu, yaitu jetzt, früher, gestern, vorgestern, heute, dan morgen. Dari keenam leksem waktu yang sudah disebutkan, kata morgen selain dikatakan deiksis waktu juga ada yang non-deiktis. Leksem waktu berdasarkan perhitungan kalender atau satuan kalender bisa bersifat deiktis. Sedangkan leksem yang menunjukkan deiksis ruang ada 148 leksem. Dari leksemleksem ruang yang ditemukan hanya terdapat 5 macam deiksis ruang yaitu hier, $d a$, dort, neben, dan auf. Ditemukan juga leksem ruang atau tempat berdasarkan arah, seperti auf, hinter, dan oben yang termasuk non-deiktis.

\section{Deiksis Waktu}

Dalam deiksis waktu (Levinson, 1983: 73), peran penutur dan mitra tutur menjadi referensi utama. Penting untuk mengetahui kapan tuturan itu dilakukan dan waktu penerimaan tuturan. Leksem waktu yang berdasarkan perhitungan kalender dapat bersifat deiktis apabila digabungkan dengan pengubah deiktis. Senada dengan itu, Rahman (2017) menyebutkan bahwa leksem waktu yang mengacu pada waktu sebelum tuturan, waktu pada saat tuturan, dan waktu setelah tuturan bersifat deiktis. Deiksis waktu juga berhubungan dalam penunjukkan hari.

Berikut deiksis waktu yang ditemukan dalam Transkripte der Hörtexte Netzwerk B1:

\section{1) Jetzt}

Leksem penunjuk waktu jetzt mengacu pada saat terjadinya tuturan yang dihasilkan oleh penutur kepada mitra tutur.

X: Können Sie bitte kurz erzählen, welche technischen Geräte Sie benützen? Und warum Ihnen die wichtig sind? Oder wichtig waren. (Dapatkah Anda memberi tahu kami perangkat yang Anda gunakan? Dan mengapa itu penting bagi Anda.)

Y: Hm, das ist gar nicht so einfach, es gibt so vieles. Aber ich war so froh, als wir an unserer Haustür einen Türöffner mit Zahlencode bekommen haben. (Hm, itu tidak mudah karena ada banyak perangkat yang saya gunakan. Tetapi saya sangat senang kami mempunyai sistem kode untuk membuka pintu.)

$\mathrm{X}$ : Und warum? (Lalu mengapa?) 
Y: Ich brauche jetzt keinen Schlüssel mehr. Das ist das Wichtigste. Ich muss nur einen Zahlencode eingeben, vier Ziffern. Und den Code habe ich im Kopf. Aber den Schlüssel habe ich schon ein paar Mal vergessen... (Yang terpenting sekarang saya tidak membutuhkan kunci. Aku membuka pintu hanya dengan sistem kode dan mengingat kodenya di kepala saya. Tetapi saya beberapa kali lupa dengan kodenya...)

Percakapan ini terjadi antara dua orang membahas tentang pembaruan perangkat. Dari percakapan tersebut dapat diketahui leksem waktu jetzt merujuk pada waktu sekarang atau saat penutur tidak lagi membutuhkan kunci karena ia sering lupa sehingga ia menggunakan sistem kode agar memudahkannya membuka pintu. Hal ini sesuai dengan teori Levinson bahwa jetzt merupakan deiksis waktu yang menunjukkan waktu pada saat penutur mengucapkan tuturan.

Pia: Du bist ja immer noch nicht fertig. Ich dachte, wir wollen jetzt los. (Kamu masih belum selesai ya. Aku pikir sudah waktunya kita pulang sekarang.)

Domenico: $\mathrm{Du}$, ich bin so müde. Im Büro war es heute so anstrengend. Ich würde gern zu Hause bleiben. (Aku sangat lelah, hari ini di kantor terasa sangat melelahkan. Aku ingin di rumah saja.)

Percakapan ini terjadi antara Pia dan Domenico di kantor. Domenico berniat untuk mengajak Pia pulang bersama tetapi Pia belum menyelesaikan perkejaannya. Dari percakapan di atas, jetzt menunjukkan waktu saat terjadinya tuturan sehingga jetzt merujuk pada saat Domenico mengajak Pia untuk pulang. Domenico mengatakan seharusnya sekarang sudah saatnya mereka pulang dari kantor.

\section{2) Früher}

Früher adalah leksem waktu yang mengacu pada waktu jauh sebelum terjadinya sebuah tuturan.

X: Gibt es ein technisches Gerät, das sie nicht mehr weggeben möchten? (Adakah perangkat teknis lain yang akan Anda bagikan?)

Y: Oh ja, die Einparkhilfe im neuen Auto, die ist echt gut. (Ya ada, alat bantu parkir pada mobil baru benar-benar bagus.)

$\mathrm{X}$ : Ist das Einparken dann wirklich einfacher? (Apakah memarkir mobil lebih mudah ?)

Y: Na klar, viel einfacher sogar! Ich sehe auf dem Monitor, wie viel Platz ist. Und es gibt ein Signal, wenn es eng wird. Dann piepst es laut. Einparken geht so viel leichter. Und es ist sicherer und viel bequemer. Ich bin früher einmal beim 
Einparken gegen ein anderes Auto gefahren, und das war sehr peinlich... (Tentu saja jauh lebih mudah! Saya hanya melihat ke monitor dan akan ada alarm ketika posisi sudah pas. Parkir jauh lebih mudah lebih aman dan nyaman. Dulu saya pernah menabrak mobil lain saat memarkir mobil dan itu memalukan....)

Percakapan ini terjadi antara dua orang yang membahas tentang pembaruan perangkat yang dimilikinya. Dari percakapan tersebut menunjukkan bahwa penutur mengatakan dulu ia pernah menabrak mobil saat memarkir tetapi sekarang sudah ada monitor dan alarm di dalam mobil sehingga ia lebih mudah untuk memarkir mobil. Leksem penunjuk waktu früher mengacu pada waktu dulu atau sebelum ada monitor dan alarm mobil yang memudahkan pada saat memarkir mobil sehingga früher merupakan deiksis waktu sesuai dengan teori Levinson bahwa früher mengacu pada waktu yang jauh sebelum tuturan itu terjadi.

3) Gestern

Leksem waktu gestern mengacu pada waktu satu hari sebelum terjadinya tuturan.

Louis: Man hat mir zugesichert, dass das Geld überwiesen wurde. Wieso dauert die Überweisung so lang? (Saya yakin uangnya sudah ditransfer. Mengapa transaksinya memakan waktu lama?)

Der Bankangestellte: Gestern war doch Feiertag, da dauert es vermutlich etwas länger. Aber ich habe einen Vorschlag. Wir können den Kredit kurzfristig erhöhen. (Kemarin adalah hari libur nasional, jadi butuh waktu lama, tetapi saya ada saran. Kami akan memperbarui kredit dalam jangka pendek...)

Percakapan ini terjadi antara Louis dan der Bankangestellte atau pegawai bank. Louis melakukan protes mengapa ia tidak bisa melakukan penarikan di ATM dan pegawai bank memberitahu bahwa kemarin (gestern) adalah hari libur nasional sehingga Louis akan membutuhkan waktu lebih lama untuk bisa menggunakan kartu kreditnya. Pada percakapan tersebut diketahui bahwa leksem waktu gestern mengkodekan waktu kemarin yaitu satu hari sebelum tuturan diucapkan oleh penutur (der Bankangestellte). Hal ini menjadikan gestern sebagai deiksis waktu. 
4) Vorgestern

Vorgestern, leksem waktu yang menunjukkan waktu dua hari sebelum terjadinya tuturan atau satu hari sebelum kemarin.

Der Verkäufer: Guten Tag, kann ich Ihnen helfen? (Halo, ada yang bisa saya bantu?)

Samira: Ja. Ich habe das Handy hier vorgestern gekauft, aber es funktioniert nicht richtig. Ich finde das wirklich sehr ärgerlich! (Ya. Sehari sebelum kemarin saya membeli handphone disini, tetapi tidak berfungsi dengan baik. Itu sangat menjengkelkan!)

Der Verkäufer: Oh, es funktioniert nicht? (Oh, handphone itu tidak berfungsi?

Samira: Na ja, es funktioniert schon, aber der Akku ist schon nach 10 Minuten leer. Ich kann also gar nicht unterwegs telefonieren. So kann ich das Handy nicht gebrauchen. (Handphone itu berfungsi, tetapi 10 menit kemudian baterainya habis. Jadi saya tidak bisa menelpon saat dalam perjalanan. Saya tidak bisa menggunakan ponsel seperti itu.)

Percakapan ini terjadi antara Samira dan penjual handphone (der Verkäufer). Samira mengatakan ia membeli handphone di tempat itu sehari sebelum kemarin (vorgestern) tetapi handphone itu tidak berfungsi dengan baik. Dari percakapan tersebut dapat diketahui, leksem waktu vorgestern merujuk pada dua hari sebelum terjadinya percakapan atau tuturan. Hal ini sesuai dengan teori yang digunakan pada penelitian ini sehingga vorgestern merupakan deiksis waktu.

\section{5) Heute}

Leksem penunjuk waktu heute mengacu pada hari ini atau hari yang sama dengan tuturan yang dituturkan oleh penutur.

Boris: Ich brauche dringend eine Pause. Und dann ist gleich die Besprechung. (Aku benar-benar membutuhkan istirahat. Sebental lagi akan ada pertemuan.) Frau Korkmaz: Was für eine Besprechung? (Pertemuan seperti apa?) Boris: Wegen dem Auftrag in Schweden. Der ist so wichtig, sagt der Chef. Darum fragt er auch immer nach: „Habt ihr das schon gemacht und das? Und ist das auch fertig?" Und heute kommen noch zwei Geschäftspartner aus Schweden zu einer Besprechung. Die ist in einer halben Stunde. (Karena pekerjaan ini di Swedia. Kata Bos ini sangat penting. Itu sebabnya ia selalu bertanya, "Sudahkah Anda menyelesaikan ini dan itu? Dan apakah itu sudah siap?" Dan hari ini dua mitra bisnis dari Swedia datang untuk rapat dalam setengah jam.)

Percakapan antara Boris dan Frau Korkmaz di kantor. Bu Korkmaz menanyakan bagaimana keadaan Boris karena Boris terlihat sibuk dengan 
pekerjaannya. Boris mengatakan ia melakukan pekerjaan dengan baik dan membutuhkan istirahat secepatnya tetapi tidak bisa karena hari ini (heute) dua mitra bisnis dari Swedia datang untuk rapat. Heute pada percakapan tersebut menunjukkan bahwa kedatangan mitra bisnis terjadi pada hari yang sama dengan terjadinya tuturan. Hal ini sesuai dengan teori Levinson yang menyebutkan sehingga leksem waktu heute pada percakapan ini merupakan deiksis waktu.

6) Morgen

Morgen mengacu pada keesokan hari atau satu hari setelah terjadinya tuturan.

X: So! Sie sind wieder gesund. Morgen können Sie nach Hause. (Anda sudah sembuh! Besok Anda bisa pulang ke rumah.)

Y: Oh, wie schön. Das ist Musik in meinen Ohren. (Bagus sekali, itu terdenger melegakan.)

Percakapan di atas terjadi antara perawat dan pasien. Dari percakapan tersebut dapat diketahui bahwa leksem waktu morgen menunjukkan waktu keesokan hari setelah tuturan itu diucapkan. Perawat mengatakan bahwa pasien sudah sembuh sehingga besok sudah bisa pulang ke rumah. Morgen termasuk dalam deiksis waktu karena mengacu pada satu hari setelah hari terjadinya tuturan sesuai dengan teori yang ada.

Selain deiksis waktu, morgen juga bisa bersifat tidak deiktis atau nondeiktis karena tidak menggantikan atau merujuk keterangan waktu. Misalnya pada:

\section{„Guten Morgen!“}

Morgen pada contoh di atas merupakan kata sapaan dan tidak ada referen yang dituju. Maka morgen pada kata sapaan tidak termasuk dalam deiksis waktu.

Leksem-leksem penunjuk waktu yang dilihat dari perhitungan kalender atau satuan kalender juga termasuk deiksis waktu apabila digabungkan dengan pengubah deiktis (deictic modifier), yaitu next, last, etc, dalam bahasa Jerman nächst, letzte, dan sebagainya. Satuan kalender yang dimaksud seperti minggu (Woche), bulan (Monat), dan tahun (Jahr) dan nama-nama hari ataupun bulan, seperti Senin (Montag), Januari (Januari), Desember (Desember), dan lain sebagainya (Levinson, 1983: 75). 
X: Haben Sie denn schon einmal in diesem Bereich gearbeitet? (Apakah Anda pernah bekerja di bidang ini?)

Y: Ja, letztes Jahr habe ich ein halbes Jahr bei der Firma Boisner und Co gearbeitet und dort alle möglichen Büroarbeiten erledigt. (Pernah, tahun lalu saya berkeja di Boisner und Co selama enam bulan dan melakukan semua jenis pekerjaan kantor disana.)

Pada percakapan di atas, Jahr merupakan satuan kalender yang digabungkan dengan letztes, sehingga penunjuk waktu letztes Jahr bersifat deiktis karena mengacu pada waktu tahun lalu atau tahun sebelum terjadinya tuturan oleh penutur.

Percakapan 1:

$\mathrm{X}$ : Was kochen wir denn heute? (Apa yang kita masak hari ini?)

Y: Ich weiß nicht. Vielleicht gibt es ein gutes Angebot? Komm, wir schauen mal hier. (Saya tidak tahu. Mungkin ada rekomendasi yang enak? Mari kita lihat disini. X: Hmm, Hühnerfleisch ... Wir könnten doch Huhn mit Zitrone und Oliven machen. (Hmm, ayam ... Kita bisa memasak ayam dengan lemon dan minyak zaitun.) Y: Ach, nicht schon wieder! Schmeckt ja gut, aber das hatten wir doch erst letzte Woche. (Jangan itu lagi! Rasanya enak tapi kita sudah makan itu minggu lalu.)

Percakapan 2:

$\mathrm{X}$ : Weißt du, was ich letzte Woche gemacht habe? Ich habe mir die Zukunft vorhersagen lassen. (Apakah kamu tahu apa yang aku lakukan minggu lalu? Aku mempunyai ramalan masa depanku.)

Y: Was??? Du glaubst doch gar nicht an so was. (Apa??? Kamu tidak seharusnya percaya hal itu.)

Sama seperti Jahr, Woche pada dua percakapan di atas sebagai satuan kalender atau perhitungan kalender bersifat deiktis karena sebelumnya ditambahkan kata letzte dan leksem waktu letzte Woche mengacu pada waktu minggu lalu atau minggu sebelumnya. Hal ini berlaku juga untuk Monat, apabila digabungkan dengan letzte maka akan bersifat deiktis.

Selain letzte, ada nächst yang dapat menjadikan satuan kalender bersifat deiktis. Seperti percakapan berikut:

X: Ach - du kaufst Wasser in Flaschen? Weißt du eigentlich, wie viel Energie es kostet, das Wasser abzufüllen und in den Supermarkt zu transportieren? Also, das Wasser lassen wir hier, unser Leitungswasser schmeckt doch super und ist gesund! (Kamu membeli air isi ulang? Tahukah kamu berapa biaya energi yang dihabiskan untuk mengisi air dan membawanya ke supermarket? Jadi biarkan airnya disini, karena air keran kita terasa enak dan menyehatkan!) 
Y: Huch, jetzt hast du mich aber erwischt. Also komm, gehen wir zur Kasse. (Oh, baiklah. Ayo kita ke kasir.)

X: Okay. - Ach schau mal, hier ist ein Flyer mit den Angeboten für nächste Woche. Den nehme ich mit. (Oke. Eh lihat, ada selebaran promo untuk minggu depan. Aku akan membawanya.)

Percakapan di atas menunjukkan deiksis waktu karena terdapat leksem waktu nächste Woche. Woche tidak bersifat deiktis atau non-deiktis jika tidak digabungkan dengan nächst, tetapi pada percakapan di atas termasuk deiktis karena nächste Woche.

Begitu juga dengan satuan kalender nama-nama hari ataupun bulan bersifat deiktis apabila ada penggabungan dengan pengubah deiktis. Jika tidak digabung dengan pengubah deiktis, maka satuan kalender tidak bisa bersifat deiktis melainkan non-deiktis sesuai dengan teori Levinson.

\section{Deiksis Ruang}

Menurut Levinson (1983: 79), deiksis ruang atau biasa yang disebut deiksis tempat berkaitan dengan lokasi yang relatif terhadap penutur, yaitu sesuai dengan lokasi penutur saat terjadinya tuturan, jarak lokasi terhadap penutur, dan lokasi berdasarkan arah terhadap penutur. Dikatakan deiksis ruang apabila dilihat dari sudut pandang atau perspektif penutur saat tuturan.

Berikut deiksis ruang yang ditemukan dalam Transkripte der Hörtexte Netzwerk B1:

1) Hier

Ruang yang mencakup lokasi penutur pada saat tuturan. Hier menunjukkan lokasi yang dekat dengan penutur.

X: Hallo und herzlich willkommen bei „Talk um Sieben“. Heute ist unser Thema „Neue Liebe, neues Glück" und ich habe zwei Gäste. Herr Dr. Kammerer, Psychologe und Paartherapeut, und Selina Giachero. Sie ist vor drei Jahren für ihre Liebe nach Italien gezogen und hat hier alles aufgegeben. Frau Giachero, erzählen Sie uns doch kurz, wie es Ihnen jetzt in Italien so geht? (Halo dan selamat datang di "Talk um Sieben". Hari ini temanya adalah "Cinta baru, kebahagiaan baru" dan saya memiliki dua tamu. Dr. Kammerer, psikolog dan terapis pasangan, dan Selina Giachero. Dia pindah ke Italia tiga tahun lalu karena cinta dan telah meninggalkan segalanya disini. Nona Giachero, ceritakan sedikir bagaimana keadaan Anda sekarang di Italia?)

Y: Ja, hallo. Es geht mir im Moment sehr gut, ich fühle mich wohl in Italien und bin glücklich verheiratet. (Ya, Halo. Saya benar-benar menikmati dengan baik, saya merasa merasa di Itali seperti rumah sendiri dan pernikahan saya bahagia.)

Percakapan ini terjadi antara pembawa acara siaran radio dan bintang 
tamu. Pembawa acara membuka acara dan menceritakan bahwa bintang tamu, Selina, tiga tahun yang lalu pindah ke Italia demi cintanya dan meninggalkan segalanya di Jerman. Dari percakapan ini dapat diketahui bahwa hier sebagai leksem ruang atau tempat merujuk pada lokasi penutur (pembawa acara) pada saat terjadinya tuturan, yaitu di Jerman. Hal ini sesuai dengan teori Levinson bahwa deiksis ruang berkaitan dengan lokasi penutur sehingga hier termasuk dalam deiksis ruang.

\section{2) Da dan Dort}

Da dan dort merupakan leksem ruang yang jauh atau tidak dekat dari lokasi penutur pada saat tuturan.

X: Haben Sie denn schon einmal in diesem Bereich gearbeitet? (Apakah Anda pernah bekerja di bidang ini?)

Y: Ja, letztes Jahr habe ich ein halbes Jahr bei der Firma Boisner und Co gearbeitet und dort alle möglichen Büroarbeiten erledigt. Und im Winter habe ich ein Praktikum bei einer Sprachschule gemacht. (Pernah, tahun lalu saya bekerja di Boisner und Co selama enam bulan dan melakukan semua jenis pekerjaan disana.)

Percakapan ini terjadi antara pelamar pekerjaan dan pihak perusahaan. Pihak perusahaan menanyakan apakah pelamar mempunyai pengalaman pekerjaan di bidang yang diinginkan, kemudia pelamar mengatakan ia pernah bekerja di Boisner und Co dan melakukan semua jenis pekerjaan kantor disana. Leksem ruang dort (disana) merujuk pada Boisner und Co. Dari percakapan tersebut dapat diketahui bahwa dort mengacu pada ruang atau tempat yang jauh dari lokasi penutur pada saat terjadinya tuturan.

X: Sie sagen, das Chemie-Studium hat Spaß gemacht. Sie waren also Studentin und in den Sommerferien Briefträgerin. Und dann waren Sie Chemikerin. (Anda berkata bahwa kuliah di bidang kimia itu menyenangkan. Jadi Anda adalah seorang mahasiswi dan selama liburan musim panas bekerja sebagai tukang pos. Dan kemudian Anda adalah seorang ahli kimia. - Tidak, itu tidak sepenuhnya benar. Kemudian saya juga bekerja sebagai pelayan di samping studi saya. Saya mendapat cukup banyak uang di sana, terutama dengan tip. Dan saya selalu memiliki banyak kontak dengan orang.)

Y: Nein, so stimmt das nicht ganz. Ich habe später auch neben meinem Studium als Kellnerin gearbeitet. Da habe ich auch ganz gut verdient, vor allem mit dem Trinkgeld. Und ich hatte immer viel Kontakt mit Menschen. (Itu tidak sepenuhnya benar. Selain studi, saya bekerja sebagai pelayan. Saya mendapat cukup banyak uang disana, terutama tip. Dan saya memiliki banyak relasi.) 
Percakapan ini terjadi antara pewawancara dan Frau Geiger dalam sebuah interview. Geiger mengatakan selain menjadi mahasiswi, ia memiliki pekerjaan sampingan sebagai pelayan. Disana $(d a)$ ia mendapatkan cukup banyak uang. Leksem waktu $d a$ (disana) merujuk pada tempat ia bekerja sebagai pelayan. Leksem penunjuk ruang $d a$ menunjukkan ruang yang jauh dari lokasi tuturan itu diucapkan. Dengan demikian, penunjuk ruang dort dan $d a$ merupakan deiksis ruang yang mengacu jarak lokasi dengan penutur.

Berbeda dengan $d a$ sebagai deiksis, $d a$ dalam percakapan di bawah ini tidak termasuk deiksis ruang karena tidak menunjukkan keterangan tempat. Dari percakapan ini diketahui bahwa penutur harus mempersiapkan dokumen untuk besok pagi karena akan diadakan rapat kembali. Leksem ruang $d a$ pada percakapan ini bukan deiksis melainkan konjungsi atau kata penghubung yang artinya "karena".

\section{X: Herein! (Silakan masuk!)}

Y: Haben Sie noch keinen Feierabend, Herr Jeschke? (Anda masih belum menyelesaikan pekerjaan, Pak Jeschke?)

X: Nein leider. Ich muss noch etwas fertig machen. Wir hatten ja heute die Besprechung mit den Geschäftspartnern aus Schweden. (Sayangnya belum. Saya masih harus menyelesaikan sesuatu. Hari ini kami mengadakan pertemuan dengan mitra bisnis kami dari Swedia.

Y: Ja, genau! Und? Wie ist es gelaufen? (Iya, benar sekali. Bagaimana hasilnya?)

$\mathrm{X}$ : Ich denke, ganz gut. Und ich muss eben noch Unterlagen für morgen früh vorbereiten, da gibt es noch einmal eine Besprechung. (Menurut saya, berjalan dengan lancar. Saya tinggal menyiapkan dokumen untuk besok pagi, karena diadakan rapat lagi.)

3) Neben

Leksem ruang neben yang artinya di samping. Neben merujuk pada lokasi berdasarkan arah terhadap penutur.

$\mathrm{X}$ : Ja, das glaube ich. Und wie geht es Ihrer Oma mit so einer „PatchworkFamilie"? (Ya, saya berpikir begitu. Dan bagaimana kabar nenek Anda dengan "keluarga campurang" seperti itu?)

Y: Warten Sie, sie steht neben mir und hört zu. Da können Sie sie gleich selbst fragen. (Sebentar, dia berdiri di samping saya dan mendengarkan. Anda dapat menanyakan langsung kepadanya.)

Percakapan ini terjadi pada sebuah siaran radio yang mewawancari 
seseorang. Seseorang ini bercerita mengenai nenek dan keluarganya. Kemudian penyiar radio menanyakan kabar sang nenek dan orang tersebut mengatakan bahwa penyiar radio bisa menanyakan secara langsung karena sang nenek berdiri di sampingnya. Leksem ruang neben menunjukkan keberadaan sang nenek terhadap penutur, yaitu di samping penutur. Leksem ruang neben mengacu lokasi, tepatnya di samping, berdasarkan arah terhadap penutur sehingga neben merupakan deiksis ruang.

4) $A u f$

Auf adalah leksem ruang yang memiliki arti di atas. Auf menunjukkan lokasi berdasarkan arah terhadap penutur.

Sport? Ach ich weiß nicht. Ich finde, Sport ist Mord. Ich habe zum Beispiel einen Kollegen, der hat sich beim Fußballspielen ganz schlimm am Fuß verletzt. Jetzt ist er zwei Wochen krankgeschrieben ... Also für mich ist das nix. Da entspanne ich mich lieber auf dem Sofa und sehe Sport im Fernsehen ... (Olahraga? Oh saya tidak tahu. Saya pikir olahraga adalah pembunuhan. Misalnya, saya memiliki rekan kerja yang mengalami cedera parah pada kakinya saat bermain sepak bola. Sekarang dia sedang cuti sakit selama dua minggu ... Yah, itu bukan apa-apa bagiku. Saya lebih suka bersantai di atas sofa dan menonton olahraga di TV ....)

Tuturan ini merupakan pendapat seseorang tentang olahraga. Ia berpikir olahraga adalah pembunuhan dan ia lebih memilih bersantai di atas sofa dan menonton olahraga di TV. Leksem ruang pada tuturan ini adalah auf yang mengacu pada keberadaan penutur di atas sofa. Hal ini sesuai dengan teori Levinson bahwa leksem ruang, auf, menunjukkan lokasi berdasarkan arah.

Menurut Levinson (1983: 82), leksem ruang yang berdasarkan arah seperti atas, bawah, samping, depan, belakang sering memunculkan ambiguitas antara deiktis dan non-deiktis. Hasil penelitian menemukan bahwa leksem ruang yang berdasarkan arah, yaitu auf, hinter, dan oben termasuk non-deiktis. Dikatakan deiktis apabila dilihat dari sudut pandang penutur atau lokasi penutur. Dikatakan non-deiktis apabila tidak mencakup penutur dalam tuturan yang terjadi seperti percakapan berikut:

X: Und dieses Bild hier? Was steht da: Bosna-Quilt, entworfen von Lucia Lienhard-Giesinger ... Was ist denn das? (Dan gambar yang disini? Terdiri dari apa 
saja: Selimut Bosna, dirancang oleh Lucia Lienhard-Giesinger ... Apa itu?

Y: Das siehst du doch. Ein Bild aus Stoff, wenn du so willst. Und ich finde das total schön. Und vor allem die Geschichte hinter dem Bild gefällt mir. (Kamu melihatnya. Gambar yang terbuat dari kain. Saya pikir itu sangat bagus. Dan saya menyukai cerita di balik gambar itu.)

Pada percakapan di atas, hinter bukan termasuk deiksis ruang melainkan bersifat tidak deiktis karena tidak menunjukkan lokasi yang relatif terhadap penutur. Kata hinter disini menjelaskan latar belakang atau sejarah dibalik gambar yang sedang dilihat oleh penutur.

Ich beginne mal mit Traumfrauen. Nun ja, unsere Studie hat ein anderes Bild gezeigt: Ganz oben auf der Wunschliste der Männer stehen nicht die ModelEigenschaften, wenn ich das so sagen darf. (Saya mulai dengan wanita impian. Nah, penelitian kami menunjukkan gambaran yang berbeda bahwa daftar teratas keinginan pria bukanlah karakeristik model, kalau boleh saya katakana seperti itu.)

$\mathrm{X}$ : Immer auf den gleichen Campingplatz? (Selalu di perkemahan yang sama?) Y: Ja, da sind wir schon seit 15 Jahren immer. Es ist wirklich schön dort. (Ya, kami sudah disana selama 15 tahun. Perkemahannya sangat bagus disana.)

Tidak berbeda dengan hinter, penunjuk ruang auf dan oben seperti pernyataan dan percakapan di atas termasuk non-deiktis karena tidak merujuk pada referen lokasi dan juga tidak menunjukkan lokasi yang relatif terhadap penutur.

\section{SIMPULAN}

Berdasarkan hasil pembahasan mengenai deiksis waktu dan deiksis ruang dalam Transkripte der Hörtexte buku ajar Netzwerk B1, ditemukan 6 macam leksem waktu yang menunjukkan deiksis waktu (jetzt, früher, gestern, vorgestern, heute, dan morgen) dan 5 macam leksem ruang atau tempat (hier, da, dort, neben, dan auf). Terdapat 61 jetzt, 19 früher, 2 gestern, 1 vorgestern, 42 heute, 11 morgen sebagai deiksis waktu. Sedangkan deiksis ruang terdapat 46 hier, 87 da, 6 dort, 6 neben, 3 auf. Selain itu, ditemukan leksem waktu yang bisa bersifat deiktis dan non-deiktis, yaitu morgen. Adapula auf, hinter, dan oben merupakan leksem ruang berdasarkan arah yang dapat bersifat tidak deiktis. Deiksis waktu berkaitan dengan kapan terjadinya tuturan yang disampaikan penutur untuk mengetahui waktu yang ditunjuk oleh leksem waktu. Deiksis ruang dikaitkan dengan lokasi yang relatif terhadap penutur. Leksem waktu dapat dikatakan tidak 
bersifat deiktis ketika tidak ada referen yang dituju. Sama seperti leksem waktu, leksem ruang dapat bersifat non-deiktis apabila tidak dilihat dari sudut pandang atau perspektif penutur. Dalam deiksis waktu dan deiksis ruang, penutur berperan sebagai referensi utama setiap tuturan untuk mengetahui penunjukkan waktu dan tempat. Dengan mengetahui deiksis waktu dan deiksis ruang, memudahkan pemahaman pendengar pada suatu perkataan atau percakapan.

Penelitian berjudul "Deiksis Waktu dan Ruang dalam Transkripte der Hörtexte Buku Ajar Netzwerk B1" dapat mempermudah pelajar bahasa asing (Bahasa Jerman) untuk memahami deiksis dari konteks tuturan dalam pelajaran bagian Hörverstehen. Penelitian ini bisa dikembangkan lagi dengan menganalisis deiksis-deiksis lain, seperti deiksis wacana atau deiksis sosial. Dengan menggunakan data yang lebih umum dan mudah didapat seperti berita ataupun wacana sehingga penelitian bisa lebih bermanfaat lagi bagi pelajar bahasa asing khususnya bahasa jerman dalam pemahaman mengenai deiksis.

\section{DAFTAR PUSTAKA}

Cahyono, B. Y. 1995. Kristal-Kristal Ilmu Bahasa. Surabaya: Airlangga University Press. Creswell, J. W. 2010. Designing and Conducting Mixed Methods Research. USA: Sage Publication.

Dengler, Stefanie (dkk). 2017a. Netzwerk Kursbuch B1.1: Transkripte der Hörtexte. Stuttgart: Ernst Klett Sprachen GmbH, (Online), (https://www.klettsprachen.de/download/2142/978-3-12-605014-2_NW_B1.1_KB_TS.pdf, diakses 17 Oktober 2020).

Dengler, Stefanie (dkk). 2017b. Netzwerk Kursbuch B1.2: Transkripte der Hörtexte. Stuttgart: Ernst Klett SPrachen GmbH, (Online), (https://www.klettsprachen.es/download/4050/978-3-12-605005-0_NW_B1.2_KB_TS1.pdf, diakses 17 Oktober 2020).

Kurniawati, Wisma (dkk). 2013. Metodologi Penelitian Sastra dan Bahasa. Surabaya: PT. Revka Petra Media.

Levinson, Stephen C. 1983. Pragmatics. London: Cambridge University Press.

Mumba, W.E. S.. 2019. "Deiksis dalam das Jugendmagazin (JUMA) Suatu Analisis Pragmatik (JUMA): Suatu Analisis Pragmatik“. Skripsi, FIB, Sastra Jerman, Universitas Sam Ratulangi, Manado.

Nunan, David. 1991. Language Teaching Methodology. USA: Precential International Group (UK) Ltd.

Purwo, B. K. 1984. Deiksis dalam Bahasa Indonesia. Jakarta: Balai Pustaka.

Rahman, Y. 2017. Bentuk dan Fungsi Deiksis Temporal dalam Bahasa Jerman dan Bahasa Indonesia. Journal Deutsch als Fremdsprache in Indonesien. 1(1), 1-9.

Sugiyono. 2015. Metode Penelitian Pendidikan (Pendekatan Kuantitatif, Kualitatif dan $R \& D)$. Penerbit CV. Alfabeta: Bandung.

UNESA. 2000. Pedoman Penulisan Artikel Jurnal. Surabaya: Lembaga Penelitian Universitas Negeri Surabaya. 